\title{
Randomised Trial of Oral Misoprostol Versus Manual Vacuum Aspiration for the Treatment of Incomplete Abortion at a Nigerian Tertiary Hospital
}

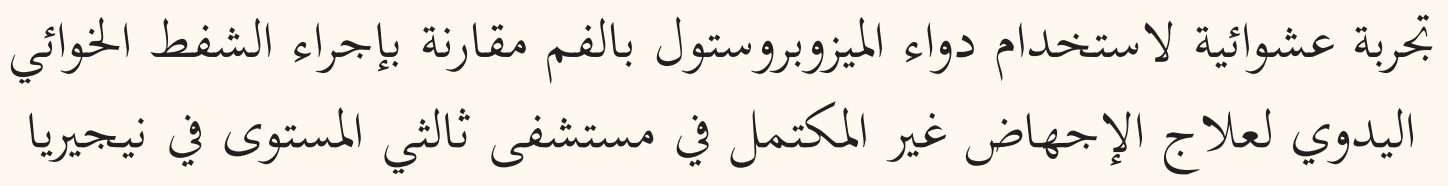

كيهيند فيمي إيبيمي، منيرالدين أديرمي إيجايا، كيكيلومو تيميلولا أديسينا

ABSTRACT: Objectives: This study aimed to compare the efficacy of oral misoprostol with manual vacuum aspiration (MVA) in first trimester incomplete abortions. Methods: This randomised controlled trial study was conducted at the University of Ilorin Teaching Hospital, Ilorin, Nigeria between April 2014 and November 2015. Pregnant women who presented with clinical features of incomplete abortion at a gestational age of 13 weeks or less were included. Patients who had profuse vaginal bleeding, an intrauterine device in situ, signs of pelvic infections or who were younger than 18 years old and had no accompanying adults to give informed consent were excluded. A total of 200 participants were randomly and equally allocated to either the MVA or misoprostol treatment group. The treatment group were given $600 \mu \mathrm{g}$ of misoprostol orally. The primary outcome measure was complete uterine evacuation, while secondary outcome measures included the need for additional surgical evacuation for failed treatment, adverse effects/complications, acceptability of and satisfaction with the treatment. Results: Both misoprostol and MVA had high complete evacuation rates, yet MVA was significantly higher (99\% versus $83 \%$, relative risk [RR]: 0.84 , confidence interval $[\mathrm{CI}]: 0.766-0.918 ; P<0.001)$. Significantly more women in the misoprostol group required additional MVA for failed treatment than in the MVA treatment group (17\% versus 1\%, RR: $16.67, \mathrm{CI}: 2.260-12.279 ; P<0.001$ ). No significant difference was found between the misoprostol and MVA treatment groups in terms of satisfaction (92.7\% versus $89.8 \%$, RR: $1.04, \mathrm{CI}: 0.946-1.127 ; P=0.473)$. Conclusion: Treatments with misoprostol and MVA had high complete uterine evacuation rates, as well as high rates of acceptability and satisfaction. However, MVA had a significantly higher complete evacuation rate than misoprostol.

Keywords: Misoprostol; Abortion Techniques; First Trimester; Incomplete Abortion; Nigeria.

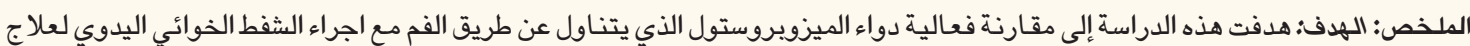

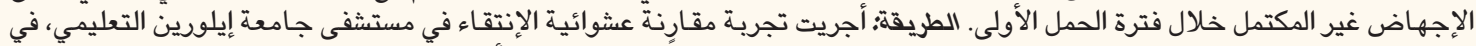

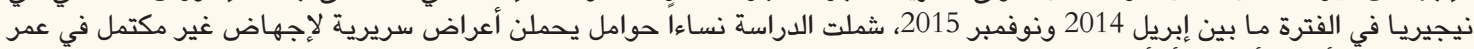

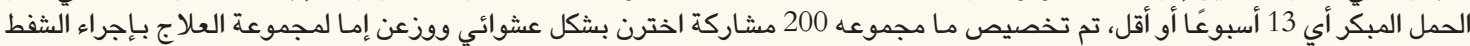

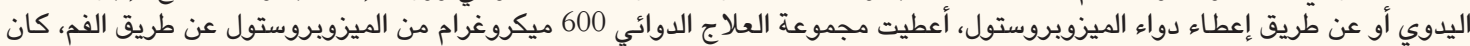

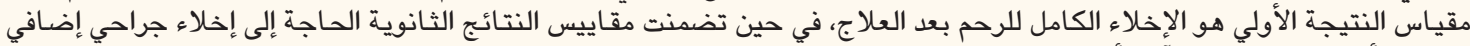

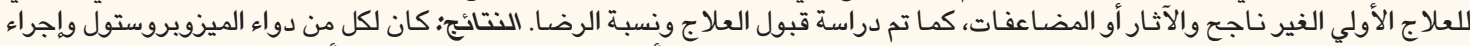

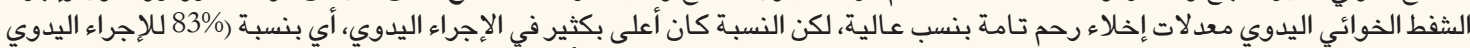

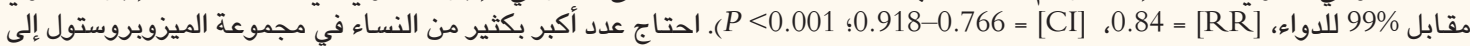

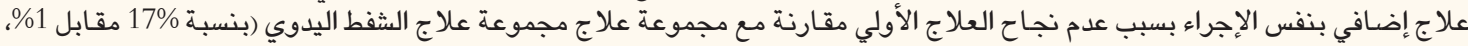
صن حئ = RR

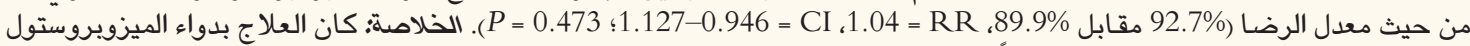

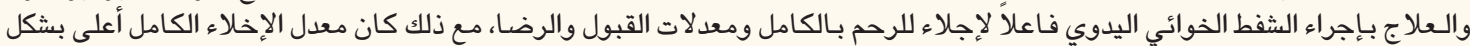

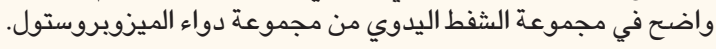

الكلمات المفتاحية: الميزويروستول؛ طرق الإجهاض؛ فصل الحمل الأول؛ إجهاض غير مكتمل؛ نيجيريا.

\section{AdvanCeS IN KNOWLEDGE}

Misoprostol and manual vacuum aspiration (MVA) had high complete evacuation rates in first trimester incomplete abortion treatment.

MVA had a significantly higher complete evacuation rate than misoprostol.

There was a high satisfaction rate in both the misoprostol and MVA treatment groups. 


\section{Application to Patient Care}

Healthcare providers can prescribe misoprostol as a good alternative to MVA for treatment of first trimester incomplete abortion in limited resource countries in order to improve post-abortion care service availability and accessibility.

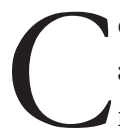

OMPLICATIONS ARISING FROM SPONTANEOUS and unsafe induced abortions have been recognised worldwide as a major public health concern and are one of the leading reasons women seek emergency care. ${ }^{1}$ A 2014 World Health Organization systematic analysis estimated that $7.9 \%$ of all maternal deaths are due to abortion; however, this figure is lower than the previous estimate of $13 \% .^{2}$ Unsafe abortions are prevalent in countries with limited resources, where abortion laws are restrictive and/or access to safe abortion services is difficult. ${ }^{2}$

In sub-Saharan Africa, access to post-abortion care (PAC) services, especially treatment of incomplete pregnancy terminations, is a priority. ${ }^{3} \mathrm{~A}$ major advancement in PAC services has been the use of manual vacuum aspiration (MVA) for uterine evacuation when uterine size is consistent with or $\leq 12$ weeks of gestation. ${ }^{4}$ However, research has shown that there is insufficient use, inadequate access to and low availability of uterine evacuation services in Nigeria. ${ }^{5}$

Medical treatment of incomplete abortion with misoprostol is an effective alternative to MVA or sharp curettage. $^{6-10}$ Most studies comparing MVA with misoprostol have shown that the former is more effective, but both have a high success rate. ${ }^{11,12}$ However, weeks et al's study contradicts this; $600 \mu \mathrm{g}$ of oral misoprostol was found to be more effective than MVA (96.3\% versus $91.5 \%$, respectively). ${ }^{13}$ Misoprostol is cheap, safe, heatstable, easy to store and requires no surgical skills to administer, making it attractive for use in sub-Saharan Africa. ${ }^{1,7,14}$ Misoprostol use for incomplete abortions could decrease the burden on healthcare facilities and skilled surgical providers while also reducing the need for surgical equipment, supplies, anaesthesia and cutting costs to healthcare systems worldwide. ${ }^{6}$ These features make misoprostol an important alternative to MVA in PAC. At the University of Ilorin Teaching Hospital, Ilorin, Nigeria, MVA was the traditional treatment for first trimester incomplete miscarriage. This study aimed to compare the outcomes of oral misoprostol with MVA in first trimester incomplete abortion treatment at the University of Ilorin Teaching Hospital in Nigeria.

\section{Methods}

This randomised controlled trial was done at the Gynaecological Emergency Ward and Gynaecology Outpatient Clinic of the Department of Obstetrics and Gynaecology at the University of Ilorin Teaching
Hospital, between April 2014 and November 2015 (trial code: PACTR201803003087264).

The subjects were pregnant women who had presented at the Gynaecological Emergency Ward with clinical features of incomplete abortion at a gestational age of $\leq 13$ weeks. Gestational age was calculated from the patient's last menstrual period to the time of miscarriage. Incomplete abortion was defined as past or present history of vaginal bleeding during index pregnancy, open cervical os, history of passing tissue and/or positive urinary pregnancy test with evidence of substantial debris in the uterus on transvaginal ultrasound. Patients with profuse vaginal bleeding, an intrauterine device in situ or signs of pelvic infections or younger than 18-years-old and had no accompanying adults to provide informed consent were excluded.

The participants were equally allocated to either the MVA or misoprostol treatment group by computergenerated random numbers using the Stat $\operatorname{Trek}^{\mathcal{O}}$ random number generator. ${ }^{15}$ The misoprostol group was labelled as treatment one and MVA was labelled treatment two. The upper limit of random numbers input into the Stat Trek $^{\odot}$ random number generator was 200 (reflecting the sample size), with a minimum value of one and a maximum of two, representing the two groups; it allowed for duplicate entries. Thereafter, a statistician created a table of 200 entries and labelled each entry with either number one or two. Participants' assigned number one were allocated to the misoprostol group and those assigned number two were part of the MVA group.

A tag was attached to each patient's folder to indicate the assigned treatment group for easy subsequent identification and follow-up. The participants, researchers and data analysers therefore were not blinded to the allocation. From the calculated sample size using a power of $80 \%$, each group in the study consisted of 100 subjects giving a total of 200 subjects, including a 10\% attrition rate. Appropriate corrections were affected after the research instrument was pretested. Following the treatment, all patients were observed in-hospital for six hours before being discharged.

Participants allocated to the misoprostol group were given $50 \mathrm{~mL}$ of water with $600 \mu \mathrm{g}$ of oral misoprostol. Participants allocated to the MVA group underwent the procedure (Ipas, Chapel Hill, North Carolina, USA) after intramuscular administration of $60 \mu \mathrm{g}$ of pentazocine and $0.5 \mathrm{mg}$ of ergometrine. The authors or research team resident doctors performed the procedures in an emergency ward operating theatre. 
This study employed a verbal rating scale translated into Yoruba that was applicable for the study participants to assess the severity of abdominal pain $(0=$ no pain, $1=$ mild pain, 2 = moderate pain, 3 = severe pain, 4 = excruciating pain). Women were not routinely given analgesics based on the unit protocol for pain management.

Participants were observed for six hours-following misoprostol administration or the MVA procedure-before being discharged from the hospital. During this observation period, any products of conception at the cervical os were removed during speculum examination. Patients were also monitored for side effects of misoprostol, including vaginal bleeding, headache, skin rash, abdominal pain, pyrexia (temperature $\geq 37.5^{\circ} \mathrm{C}$ ), chills, nausea, vomiting, headache, diarrhoea and complications of MVA such as uterine perforation. Vaginal bleeding was visually assessed based on patients' reports as either absent, mild, moderate or severe. During the observation period, an interviewer administered a questionnaire to the participants in both groups to assess adverse effects, pain and blood loss. Adverse effects were treated according to standard pain management protocols. Prior to discharge, the participants were given the names and contact details of the researchers and research assistants in case of complications or if they wanted more information about their treatment. Packed cell volume was estimated one week before and after treatment in each group.

Follow-up appointments at the Gynaecological Clinic were scheduled for one-week post-procedure for women in both groups to confirm their abortion status or in case of complications. All women underwent ultrasound assessment irrespective of their symptoms and clinical findings. Transvaginal ultrasound was used for further assessment due to its sensitivity. The same team of radiologists performed the ultrasound investigations at diagnosis and follow-up. Transvaginal ultrasound findings of an anteroposterior diameter of $>1.5 \mathrm{~cm}$ was regarded as significant debris.

In this study, treatment failure was defined as incomplete uterine evacuation warranting additional MVA based on persistent vaginal bleeding and/or ultrasound findings indicating significant debris. In such a situation, a sample was sent for histological evaluation. At the oneweek post-treatment follow-up, all participants were asked a series of questions on the treatment's adverse effects, acceptability and their satisfaction.

Data were analysed using Statistical Package for the Social Sciences (SPSS), Version 21.0 (IBM, Corp., Armonk, New York, USA). The primary outcome measure was complete uterine evacuation, while secondary outcome measures included the need for additional surgical evacuation, adverse drug effects/surgical complications and satisfaction with treatment. Levels of statistical signif- icance were tested via a Chi-square test, a Mann-Whitney U test, Student's t-test and by calculating relative risk (RR) with a 95\% confidence interval (CI) applied as appropriate. A value of $P<0.05$ was considered statistically significant.

The Ethical Committee of the University of Ilorin Teaching Hospital approved the study (ERC PAN/2014/ 01/1264). Participants gave informed consent and their data were treated confidentially. The participants did not bear any service costs and no incentive was provided in any form.

\section{Results}

A total of 238 subjects were screened for eligibility, of which 200 subjects satisfied the inclusion criteria and subsequently 100 participants were allocated to each group in the study. In total, 38 subjects were excluded from the study because of excessive vaginal bleeding $(\mathrm{n}=23)$ or refusal to participate $(\mathrm{n}=15)$. In the misoprostol group, four patients made unscheduled visits to the hospital 3-4 days after treatment due to bleeding per vaginam and therefore were assigned to the treatment failure category. Two MVA patients were lost to follow-up and were therefore excluded from the analysis [Figure 1].

The baseline demographic and reproductive variables were similar in both groups [Table 1]. Mean gestational age at miscarriage for the misoprostol and MVA groups

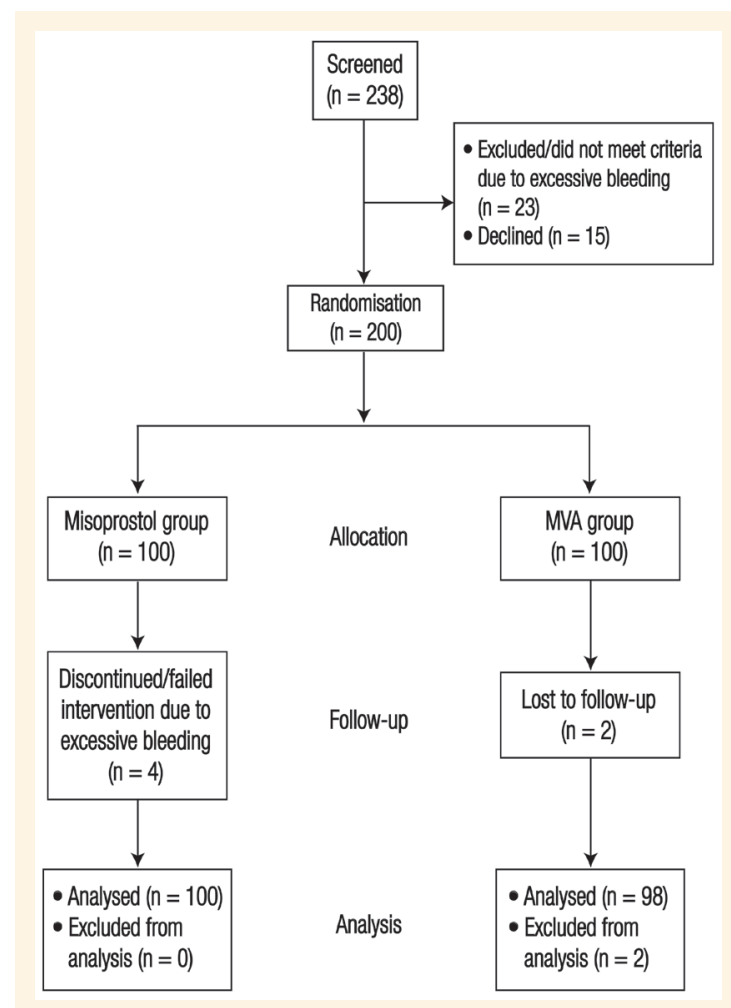

Figure 1: Flow of participants through the enrolment, allocation, follow-up and analysis stages of the study. $M V A=$ manual vacuum aspiration . 
Table 1: Characteristics of patients who had been given oral misoprostol and/or manual vacuum aspiration in first trimester incomplete abortions at the University of Ilorin Teaching Hospital, Ilorin, Nigeria $(\mathrm{N}=200)$

\begin{tabular}{|c|c|c|c|c|}
\hline \multirow[t]{2}{*}{ Characteristic } & \multicolumn{3}{|c|}{ n (\%) } & \multirow{2}{*}{$\begin{array}{c}P \\
\text { value }^{*}\end{array}$} \\
\hline & Misoprostol & MVA & Total & \\
\hline \multicolumn{5}{|c|}{ Age group in years } \\
\hline$\leq 19$ & $5(5)$ & $0(0)$ & $5(2.5)$ & 0.074 \\
\hline $20-24$ & $21(21)$ & $12(12)$ & $33(16.5)$ & 0.117 \\
\hline $25-29$ & $38(38)$ & $44(44)$ & $82(41)$ & 0.508 \\
\hline $30-34$ & $23(23)$ & $32(32)$ & $55(27.5)$ & 0.225 \\
\hline$\geq 35$ & $13(13)$ & $12(12)$ & $25(12.5)$ & 0.842 \\
\hline Mean \pm SD & $28.38 \pm 5.51$ & $28.44 \pm 3.31$ & - & $0.93^{\dagger}$ \\
\hline \multicolumn{5}{|l|}{ Occupation } \\
\hline Housewife & $9(9)$ & $3(3)$ & $12(6)$ & 0.083 \\
\hline Student & $9(9)$ & $5(5)$ & $14(7)$ & 0.285 \\
\hline Employed & $76(76)$ & $84(84)$ & $160(80)$ & 0.527 \\
\hline Unemployed & $6(6)$ & $8(8)$ & $14(7)$ & 0.593 \\
\hline \multicolumn{5}{|c|}{ Educational status } \\
\hline $\begin{array}{l}\text { Primary } \\
\text { education }\end{array}$ & $3(3)$ & $2(2)$ & $5(2.5)$ & $0.655^{\ddagger}$ \\
\hline $\begin{array}{l}\text { Secondary } \\
\text { education }\end{array}$ & $9(9)$ & $6(6)$ & $15(7.5)$ & 0.438 \\
\hline $\begin{array}{l}\text { Post-secondary } \\
\text { education }\end{array}$ & $7(7)$ & $9(9)$ & $16(8)$ & 0.617 \\
\hline $\begin{array}{l}\text { Post-graduate } \\
\text { education }\end{array}$ & $81(81)$ & $83(83)$ & $164(82)$ & 0.876 \\
\hline \multicolumn{5}{|l|}{ Marital status } \\
\hline Married & $91(91)$ & 94. (94) & $185(92.5)$ & 0.825 \\
\hline Single & $5(5)$ & $3(3)$ & $8(4)$ & 0.480 \\
\hline $\begin{array}{l}\text { Unwed } \\
\text { partnership }\end{array}$ & $4(4)$ & $3(3)$ & $7(3.5)$ & 0.706 \\
\hline \multicolumn{5}{|c|}{ Estimated gestational age in weeks } \\
\hline $5-7$ & $36(36)$ & $32(32)$ & $68(34)$ & 0.628 \\
\hline $8-10$ & $62(62)$ & $68(68)$ & $130(65)$ & 0.599 \\
\hline $11-13$ & $2(2)$ & $0(0)$ & $2(1)$ & 0.157 \\
\hline
\end{tabular}

were $8.13 \pm 1.45$ and $8.17 \pm 1.14$ weeks, respectively $(P=0.832)$.

The misoprostol and MVA groups had high complete evacuation rates; however, MVA had a significantly higher rate (83\% versus 99\%, RR: 0.84, CI: 0.766-0.918; $P<0.001)$. MVA had a significantly higher complete evacuation rate than misoprostol in the 8-10 weeks' gestational age group [Table 2].

Significantly more participants in the misoprostol group required additional MVA for treatment failure than in the MVA group (17\% versus 1\%, RR: 16.67 , CI: 2.260-12.279; $P<0.001$ ) [Table 3]. Of the 17 (17\%) participants in the misoprostol group who required add-
Table 2: Primary outcome measures of first trimester incomplete abortions using oral misoprostol and manual vacuum aspiration $(\mathrm{N}=200)$

\begin{tabular}{|c|c|c|c|c|}
\hline \multirow[t]{2}{*}{ Outcome } & \multicolumn{2}{|c|}{ n (\%) } & \multirow{2}{*}{$\begin{array}{c}\text { RR } \\
(95 \% \mathrm{CI})\end{array}$} & \multirow{2}{*}{$\begin{array}{c}P \\
\text { value }\end{array}$} \\
\hline & $\begin{array}{c}\text { Misoprostol } \\
\text { group } \\
(\mathbf{n}=100)\end{array}$ & $\begin{array}{l}\text { MVA } \\
\text { group } \\
(\mathbf{n}=98) *\end{array}$ & & \\
\hline $\begin{array}{l}\text { Complete } \\
\text { evacuation }\end{array}$ & $\begin{array}{c}83 \\
(83)\end{array}$ & $\begin{array}{c}97 \\
(99)\end{array}$ & $\begin{array}{c}0.84 \\
(0.766-0.918)\end{array}$ & $<0.001$ \\
\hline \multicolumn{5}{|c|}{ Gestational age compared against complete evacuation in weeks } \\
\hline $5-7$ & $\begin{array}{l}31 / 36 \\
(86.1)\end{array}$ & $\begin{array}{l}30 / 31 \\
(96.8)\end{array}$ & $\begin{array}{c}1.01 \\
(0.667-1.538)\end{array}$ & 0.953 \\
\hline $8-10$ & $\begin{array}{l}51 / 62 \\
(82.3)\end{array}$ & $\begin{array}{l}67 / 67 \\
(100)\end{array}$ & $\begin{array}{c}0.75 \\
(0.590-0.943)\end{array}$ & 0.013 \\
\hline $11-13$ & $\begin{array}{l}1 / 2 \\
(50)\end{array}$ & $\begin{array}{l}0 / 0 \\
(0)\end{array}$ & - & 0.321 \\
\hline
\end{tabular}

$R R=$ relative risk; $C I=$ confidence interval; $M V A=$ manual vacuum aspiration.

"Two women were lost to follow-up in the MVA group and were not included.

itional treatment, eight (47.1\%) participants had products of conception in the debris sample. Significantly higher proportions of participants in the MVA group experienced moderate to severe abdominal pain than in the misoprostol group (99\% versus 33.3\%, RR: 0.34, CI: $0.254-0.447 ; P<0.001)$. However, more participants in the misoprostol group had moderate to severe vaginal bleeding than in the MVA group (29.2\% versus 12.2\%, RR: 2.30, CI: 1.346-4.590; $P<0.001)$. Pyrexia was the most common adverse effect $(40.6 \%)$ in the misoprostol group, followed by nausea (12.5\%), chills (7.3\%) and vomiting (6.3\%); in the MVA group, nausea (7.1\%) and vomiting (4.1\%) were the most common adverse effects. Both misoprostol and MVA groups had high satisfaction rates (92.7\% versus $89.8 \%$, RR: 1.04 , CI: $0.946-1.127 ; P=0.473)$. Most participants in both groups expressed the desire to choose the respective method again and would recommend that method to their friends [Table 3].

\section{Discussion}

In the current study, the complete uterine evacuation rate was high in both the misoprostol and MVA groups, with MVA having a significantly higher success rate (83\% versus 99\%; $P<0.001)$. This finding is in agreement with other studies in Burkina Faso, Tanzania, Ghana, Finland and Ecuador. ${ }^{10-12,14,16}$ The success rate of $600 \mu \mathrm{g}$ oral misoprostol in this study was comparable with findings from varying dosages and routes of administration of misoprostol used in other studies. ${ }^{8,17,18}$ Similarly, a recent Cochrane Database Systematic Review that compared different routes of administration of misoprostol with MVA showed no clear evidence to suggest that one regimen was superior to another. ${ }^{19}$ Contrary to this and 
Table 3: Secondary outcome measures of first trimester incomplete abortions using oral misoprostol and manual vacuum aspiration $(\mathrm{N}=200)$

\begin{tabular}{|c|c|c|c|c|}
\hline \multirow[t]{2}{*}{ Outcome } & \multicolumn{2}{|c|}{ n (\%) } & \multirow{2}{*}{$\begin{array}{c}\text { RR } \\
(95 \% \mathrm{CI})\end{array}$} & \multirow{2}{*}{$\begin{array}{c}P \\
\text { value }\end{array}$} \\
\hline & $\begin{array}{c}\text { Misoprostol } \\
\text { group } \\
(\mathbf{n}=100)\end{array}$ & $\begin{array}{l}\text { MVA } \\
\text { group } \\
(\mathbf{n}=98)\end{array}$ & & \\
\hline $\begin{array}{l}\text { Required an } \\
\text { additional } \\
\text { MVA }\end{array}$ & $\begin{array}{c}17 \\
(17)\end{array}$ & $\begin{array}{c}1 \\
(1)\end{array}$ & $\begin{array}{c}16.67 \\
(2.260-12.279)\end{array}$ & $<0.001$ \\
\hline $\begin{array}{l}\text { Total } \\
\text { participants* }\end{array}$ & $\begin{array}{c}96 \\
(100)\end{array}$ & $\begin{array}{c}98 \\
(100)\end{array}$ & & \\
\hline $\begin{array}{l}\text { Moderate-to- } \\
\text { severe abdom- } \\
\text { inal pain }\end{array}$ & $\begin{array}{c}32 \\
(33.3)\end{array}$ & $\begin{array}{c}97 \\
(99)\end{array}$ & $\begin{array}{c}0.34 \\
(0.254-0.447)\end{array}$ & $<0.001$ \\
\hline $\begin{array}{l}\text { Moderate-to- } \\
\text { severe vaginal } \\
\text { bleeding }\end{array}$ & $\begin{array}{c}28 \\
(29.2)\end{array}$ & $\begin{array}{c}12 \\
(12.2)\end{array}$ & $\begin{array}{c}2.30 \\
(1.346-4.590)\end{array}$ & $<0.001$ \\
\hline \multicolumn{5}{|c|}{ Adverse effects/complications } \\
\hline Chills & $\begin{array}{c}7 \\
(7.3)\end{array}$ & $\begin{array}{c}0 \\
(0)\end{array}$ & - & 0.006 \\
\hline Headache & $\begin{array}{c}3 \\
(3.1)\end{array}$ & $\begin{array}{c}2 \\
(2)\end{array}$ & $\begin{array}{c}1.55 \\
(0.262-8.962)\end{array}$ & 0.490 \\
\hline Nausea & $\begin{array}{c}12 \\
(12.5)\end{array}$ & $\begin{array}{c}7 \\
(7.1)\end{array}$ & $\begin{array}{c}1.76 \\
(0.720-4.256)\end{array}$ & 0.155 \\
\hline Vomiting & $\begin{array}{c}6 \\
(6.3)\end{array}$ & $\begin{array}{c}4 \\
(4.1)\end{array}$ & $\begin{array}{c}1.54 \\
(0.446-5.257)\end{array}$ & 0.466 \\
\hline Diarrhoea & $\begin{array}{c}2 \\
(2.1)\end{array}$ & $\begin{array}{c}0 \\
(0)\end{array}$ & - & 0.244 \\
\hline Rash & $\begin{array}{c}1 \\
(1)\end{array}$ & $\begin{array}{c}0 \\
(0)\end{array}$ & - & 0.495 \\
\hline Pyrexia & $\begin{array}{c}39 \\
(40.6)\end{array}$ & $\begin{array}{c}0 \\
(0)\end{array}$ & - & $<0.001$ \\
\hline $\begin{array}{l}\text { Uterine } \\
\text { perforation }\end{array}$ & $\begin{array}{c}0 \\
(0)\end{array}$ & $\begin{array}{c}0 \\
(0)\end{array}$ & - & - \\
\hline \multicolumn{5}{|c|}{ Acceptability of method } \\
\hline $\begin{array}{l}\text { Satisfied with } \\
\text { the method }\end{array}$ & $\begin{array}{c}89 \\
(92.7)\end{array}$ & $\begin{array}{c}88 \\
(89.8)\end{array}$ & $\begin{array}{c}1.04 \\
(0.946-1.127)\end{array}$ & 0.473 \\
\hline $\begin{array}{l}\text { Simple, quick } \\
\text { and successful } \\
\text { were the best } \\
\text { features }\end{array}$ & $\begin{array}{c}83 \\
(86.5)\end{array}$ & $\begin{array}{c}90 \\
(91.8)\end{array}$ & $\begin{array}{c}0.94 \\
(0.853-1.039)\end{array}$ & 0.228 \\
\hline $\begin{array}{l}\text { Good couns- } \\
\text { elling/care were } \\
\text { the best features }\end{array}$ & $\begin{array}{c}60 \\
(62.5)\end{array}$ & $\begin{array}{c}80 \\
(81.6)\end{array}$ & $\begin{array}{c}0.77 \\
(0.639-0.918)\end{array}$ & 0.003 \\
\hline $\begin{array}{l}\text { Pain was the } \\
\text { worst feature }\end{array}$ & $\begin{array}{c}5 \\
(5.2)\end{array}$ & $\begin{array}{c}29 \\
(29.6)\end{array}$ & $\begin{array}{c}0.18 \\
(0.071-0.436)\end{array}$ & $<0.001$ \\
\hline $\begin{array}{l}\text { Vaginal bleeding } \\
\text { was the worst } \\
\text { feature }\end{array}$ & $\begin{array}{c}11 \\
(11.5)\end{array}$ & $\begin{array}{c}9 \\
(9.2)\end{array}$ & $\begin{array}{c}1.25 \\
(0.542-2.875)\end{array}$ & 0.602 \\
\hline $\begin{array}{l}\text { Would choose } \\
\text { same method } \\
\text { again }\end{array}$ & $\begin{array}{c}90 \\
(93.8)\end{array}$ & $\begin{array}{c}88 \\
(89.8)\end{array}$ & $\begin{array}{c}1.04 \\
(0.960-1.136)\end{array}$ & 0.317 \\
\hline $\begin{array}{l}\text { Would rec- } \\
\text { ommend chosen } \\
\text { method to friend }\end{array}$ & $\begin{array}{c}89 \\
(92.7)\end{array}$ & $\begin{array}{c}88 \\
(89.8)\end{array}$ & $\begin{array}{c}1.03 \\
(0.946-1.127)\end{array}$ & 0.473 \\
\hline
\end{tabular}

$R R=$ relative risk; $C I=$ confidence interval; $M V A=$ manual vacuum aspiration *Four women in the misoprostol group who made an unscheduled visit and two women lost to follow-up in the MVA group were not included. other findings, Weeks et al's study in Uganda found a slightly higher success rate among the misoprostol group than the MVA group, although the difference was not statistically significant $(96.3 \%$ versus $91.5 \% ; P=0.43) .{ }^{13}$ This study shows that MVA is more effective than misoprostol in treatment of incomplete abortion in the 8-10 week gestational age group. However, treatment outcomes of MVA and misoprostol depended on providers' skills and quality of the misoprostol.

The higher failure rate and need for MVA in this study could be due to the use of transvaginal ultrasonography to assess complete emptiness of the uterine cavity as opposed to abdominal ultrasonography and clinical assessment used for post-intervention evaluation in other studies. ${ }^{10,11,20}$ However, transvaginal ultrasonography is more sensitive than abdominal ultrasonography and clinical assessment. ${ }^{21}$

This study, as has been observed in another study, demonstrated higher cases of pyrexia, nausea and chills among the misoprostol versus the MVA group. ${ }^{19}$ These symptoms are common side effects of misoprostol, with pyrexia being the most common side effect as a result of the drug's action (prostaglandin E1 analogue) on the central thermoregulatory centre..$^{22}$ MVA was identified as more painful than misoprostol, which is in agreement with Shwekerela et al. and Bique et al's studies but in contrast with Niinimäki et al's findings. ${ }^{10,12,23}$ Misoprostol causes uterine cramping and bleeding during expulsion of the remaining products of conception; however, these side effects are transient and tolerable.

As in other studies, the current participants indicated high satisfaction with both misoprostol and MVA.,11,16 This finding was contrary to a study by Shwekerela et al., where the misoprostol group had a significantly higher percentage of participant satisfaction than the MVA group $(75 \%$ versus $55 \% ; P=0.001) .{ }^{10}$ A comparably high percentage of participants in both groups in this study expressed a desire to recommend their treatment method to a friend and would use the same approach again, which is in-line with the findings of Dao et al. ${ }^{11}$ In contrast, Shwekerela et al's study determined that a significantly higher proportion of participants in the misoprostol group would recommend the treatment to a friend than in the MVA group ( $95 \%$ versus $75 \% ; P<0.001$ ). ${ }^{10}$ Niinimäki et al's study found that fewer participants in the misoprostol group expressed a desire to choose the same treatment method in the future because of pain. ${ }^{12}$

Limitations of this study included the subjective visual estimation of vaginal bleeding and the small sample size; hence, it was difficult to assess the significance of some outcomes that were of low occurrence. 


\section{Conclusion}

Both misoprostol and MVA had high rates of satisfaction and complete uterine evacuation, which could ultimately reduce maternal death from abortion. However, MVA had a significantly higher complete evacuation rate than misoprostol. Misoprostol is cheap, readily available and does not require any surgical equipment or expertise. Therefore, healthcare providers should be encouraged to prescribe misoprostol for treatment of first trimester incomplete miscarriage as a form of task-shifting in limited resource countries and to improve the availability and accessibility of PAC services.

\section{CONFLICT OF INTEREST}

The authors declare no conflicts of interest.

\section{FUNDING}

No funding was received for this study.

\section{References}

1. American College of Obstetricians and Gynecologist. ACOG committee opinion No. 427: Misoprostol for postabortion care. Obstet Gynecol 2009; 113:465-8. https://doi.org/10.1097/AOG.0b 013e31819930f9.

2. Say L, Chou D, Gemmill A, Tunçalp Ö, Moller AB, Daniels J, et al Global causes of maternal death: A WHO systematic analysis. Lancet Glob Health 2014; 2:e323-33. https://doi.org/10.1016/ s2214-109x(14)70227-x.

3. Adefuye PO, Sule-Odu AO, Olatunji AO, Lamina MA, Oladapo OT. Maternal deaths from induced abortions. Trop J Obstet Gynaecol 2003; 20:101-4. https://doi.org/10.4314/tjog.v20i2.14410.

4. World Health Organization. Safe abortion: Technical and policy guidance for health systems. From: apps.who.int/iris/bitstream/ handle $/ 10665 / 70914 / 9789241548434$ eng.pdf? sequence $=1$ Accessed: Nov 2018

5. Etuk SJ, Ebong IF, Okonofua FE. Knowledge, attitude and practice of private medical practitioners in Calabar towards post-abortion care. Afr J Reprod Health 2003; 7:55-64. https://doi.org/10.2307/ 3583289 .

6. Blum J, Winikoff B, Gemzell-Danielsson K, Ho PC, Schiavon R, Weeks A. Treatment of incomplete abortion and miscarriage with misoprostol. Int J Gynecol Obstet 2007; 99:S186- 9. https://doi.org/10. 1016/j.ijgo.2007.09.009

7. Ambusaidi Q, Zutshi A. Effectiveness of misoprostol for induction of first-trimester miscarriages: Experience at a single tertiary care centre in Oman. Sultan Qaboos Univ Med J 2015; 15:e534-8. https://doi.org/10.18295/squmj.2015.15.04.016.

8. Dabash R, Ramadan MC, Darwish E, Hassanein N, Blum J, Winikoff B. A randomized controlled trail of 400- $\mu$ g sublingua misoprostol versus manual vacuum aspiration for the treatment of incomplete abortion in two Egyptian hospitals. Int J Gynaecol Obstet 2010; 111:131-5. https://doi.org/10.1016/j.ijgo.2010.06.021.
9. Taylor J, Diop A, Blum J, Dolo O, Winikoff B. Oral misoprostol as an alternative to surgical management for incomplete abortion in Ghana. Int J Gynaecol Obstet 2011; 112:40-4. https://doi.org/10. 1016/j.ijgo.2010.08.022.

10. Shwekerela B, Kalumuna R, Kipingili R, Mashaka N, Westheimer E, Clark W, et al. Misoprostol for treatment of incomplete abortion at the regional hospital level: Results from Tanzania. BJOG 2007; 114:1363-7. https://doi.org/10.1111/j.1471-0528.2007.01469.x.

11. Dao B, Blum J, Thieba B, Raghavan S, Ouedraego M, Lankoande J, et al. Is misoprostol a safe, effective and acceptable alternative to manual vacuum aspiration for postabortion care? Results from a randomised trial in Burkina Faso, West Africa. BJOG 2007;114:1368-75.https://doi.org/10.1111/j.1471-0528.2007.01468.x.

12. Niinimäki M, Jouppila P, Martikainen H, Talvensaari-Mattila A. A randomized study comparing efficacy and patient satisfaction in medical or surgical treatment of miscarriage. Fertil Steril 2006; 86:367-72. https://doi.org/10.1016/j.fertnstert.2005.12.072.

13. Weeks A, Alia G, Blum J, Winikoff B, Ekwaru P, Durocher J, et al. A randomized trial of misoprostol compared with manual vacuum aspiration for incomplete abortion. ObstetGynecol 2005; 106:540-7. https://doi.org/10.1097/01.AOG.0000173799.82687.dc

14. Fawole AO, Diop A, Adeyanju AO, Aremu OT, Winikoff B. Misoprostol as first-line treatment for incomplete abortion at a secondary-level health facility in Nigeria. Int J Gynaecol Obstet 2012; 119:170-3. https://doi.org/10.1016/j.ijgo.2012.06.012.

15. Stat Trek. Random Number Generator. From: www.stattrek.com/ statistics/random-number-generator.aspx Accessed: Nov 2018.

16. Montesinos R, Durocher J, León W, Arellano M, Peña M, Pinto E, et al. Oral misoprostol for the management of incomplete abortion in Ecuador. Int J Gynaecol Obstet 2011; 115:135-9. https://doi. org/10.1016/j.ijgo.2011.06.015.

17. Diop A, Raghavan S, Rakotovao JP, Comendant R, Blumenthal PD, Winikoff B. Two routes of administration for misoprostol in the treatment of incomplete abortion: A randomized clinical trial. Contraception 2009; 79:456-62. https://doi.org/10.1016/j.contra ception.2008.11.016

18. Shochet T, Diop A, Gaye A, Nayama M, Sall AB, Bukola F, et al. Sublingual misoprostol versus standard surgical care for treatment of incomplete abortion in five sub-Saharan African countries. BMC Pregnancy Childbirth 2012; 12:127. https://doi.org/10.11 86/1471-2393-12-127.

19. Kim C, Barnard S, Neilson JP, Hickey M, Vazquez JC, Dou L. Medical treatments for incomplete miscarriage. Cochrane Database Syst Rev 2017; 1:CD007223. https://doi.org/10.1002/146 51858.CD007223.

20. Blandine T, Ouattara AZ, Coral A, Hassane C, Clotaire H, Dao B, et al. Sublingual [corrected] misoprostol as first-line care for incomplete abortion in Burkina Faso. Int J Gynaecol Obstet 2012; 119:166-9. https://doi.org/10.1016/j.ijgo.2012.05.036.

21. Dipi RM, Amin MS, Islam MN, Khan NA, Chaiti MM, Hossain MM. Comparison of transabdominal and transvaginal sonography in the evaluation of uterine mass with histological correlation. Mymensingh Med J 2013; 22:69-74.

22. Elati A, Weeks A. Risk of fever after misoprostol for the prevention of postpartum hemorrhage: A meta-analysis. Obstet Gynecol 2012; 120:1140-8.

23. Bique C, Ustá M, Debora B, Chong E, Westheimer E, Winikoff B. Comparison of misoprostol and manual vacuum aspiration for the treatment of incomplete abortion. Int J Gynaecol Obstet 2007; 98:222-6. https://doi.org/10.1016/j.ijgo.2007.05.003. 